\title{
Electronic Word-of-Mouth Communication for Local Service Providers
}

\author{
Nora Schütze \\ "Undoubtedly, philosophers are in the right when they" \\ tell us that nothing is great or little otherwise than by \\ comparison. \\ Gulliver's Travels \\ by Jonathan Swift (1667-1745)
}

\begin{abstract}
Word-of-mouth communication is a valuable means of marketing for small, local service providers. Face-to-face transmission is most prevalent, but electronic word-of-mouth is on the rise. Through the results of an agent-based simulation, this article shows that the penetration of word-of-mouth for a small service provider, who is locally restricted due to the inseparability of production and consumption, could benefit less from a growth in word-of-mouth connections than a larger service provider. Only if the added electronic connections are mainly local, small and larger service providers have similar effects on the penetration of word-of-mouth. The article includes a discussion of how small service providers could react to this threat.
\end{abstract}

\section{Introduction}

Word-of-mouth communication has become a hot research topic in recent years because of its effectiveness as a tool for marketing (East et al., 2005; Trusov et al., 2009). Although word-of-mouth is often studied in the context of selling goods (Libai et al., 2009), it is even more important to the sales of services (van den Bulte \& Wuyts, 2007; Zeithaml, 1981). Services are largely intangible and have credence qualities (Zeithaml et al., 1996), leaving potential customers uncertain about the quality of the service. In particular, small service providers - such hairdressers or plumbers - heavily rely on word-of-mouth communication by their customers, because they are often locally restricted due to their small number of staff and the inseparability of production and consumption (Zeithaml et al., 1996; Lovelock, 2001).

In recent years, the electronic version of word-ofmouth communication grew strongly and now accounts for $10 \%$ of all word-of-mouth contacts (Carl, 2006; Keller \& Berry, 2006; Keller \& Fay, 2012). Electronic word-of-mouth is based on media with low synchronicity requirements, other than, for example, face-to-face communication. Such low- synchronicity media are especially suited to familiar tasks and to situations where transmitting information is more important than creating common understanding (Dennis et al., 2008), both of which are relevant with electronic word-of-mouth. Lower synchronicity also means that spatial proximity is less important for electronic wordof-mouth than other forms of word-of-mouth (De Bruyn \& Lilien, 2008). The Internet is an essentially global medium (Lagrosen, 2005; Subramaniam et al., 2000), and even though many online contacts might actually sit next door, the overall proximity of online contacts can be considered to be lower than the proximity of face-to-face contacts who exchange traditional wordof-mouth communication (Wellman, 1996).

Now, if word-of-mouth is local and electronic word-ofmouth is less so, the penetration of word-of-mouth for small local service providers could suffer. With mainly non-electronic communication, people will exchange word-of-mouth communication about a local service provider with the people they meet every day, face to face. Most of the recipients of this communication are then able to purchase the services of this provider because they live nearby. If people engage more and more 


\title{
Electronic Word-of-Mouth Communication for Local Service Providers
}

\author{
Nora Schütze
}

in electronic communication, the amount of communication (and of word-of-mouth) heavily increases, and a certain portion of the new communication goes to non-local recipients. Such non-local electronic word-ofmouth leaves the realm of a small service provider. People who receive the communication, but do not live close to the service provider, cannot purchase the service and will also not pass on the electronic word-ofmouth.

The objective of the study is to show the impact that electronic word-of-mouth could have on small local service providers. First, the relevant theories are described to show how hypotheses were developed. Next, the methodology and analysis of an agent-based simulation of a word-of-mouth are presented. Finally, several recommendations are given to help small service providers benefit from increases in electronic word-ofmouth communication.

\section{Theoretical Overview and Hypotheses}

Word-of-mouth is defined as communication between people about brands, goods, or services (Zeithaml, 1981; van den Bulte \& Lilien, 2001) that induces a change in the behaviour or the preferences of its addressee (Libai et al., 2010). This change is brought about by mere communication, observation (Garber et al., 2004; Godes et al., 2005; Libai et al., 2010), and social pressure once a certain number of people within a person's network all start to behave in a certain way (e.g., a threshold model: Delre et al., 2007a; Granovetter, 1978). Word-of-mouth processes are usually self-reinforcing (Winch \& Bianchi, 2006). The impact of word-of-mouth depends on characteristics of the customer, the product, the market, the message, the channel, and on the relationship between the sender and addressee (Arndt, 1967; Libai et al., 2010). This article focuses on the relationship between sender and addressee, and mainly examines their physical proximity. Other important aspects of this relationship are tie strength, demographic similarity, or perceptual affinity (Bruyn \& Lilien, 2008), but these aspects are beyond the scope of this study.

Electronic communication and electronic word-ofmouth are on the rise, altering the nature and effects of word-of-mouth communication. Two developments are associated with rising electronic communication relevant to word-of-mouth. First, a strong growth in the amount of word-of-mouth connections can be expected, because electronic communication can easily be shared and copied. Second, parts of these new connec- tions will be non-local, given that electronic word-ofmouth can go to contacts anywhere in the world, whereas traditional word-of-mouth mostly addresses people in the same area. Thus, the non-local share of all connections increases. Our analysis is informed by the literature on the role of proximity in innovation diffusion. It has been shown that spatial proximity has a positive influence on the diffusion of innovation (Agrawal et al., 2008; Bell \& Song, 2007; Bronnenberg \& Mela, 2004; Choi et al., 2010; Garber et al., 2004).

From this consideration, we derive two hypotheses: First, we argue that a mere rise in the number of connections of customers can be detrimental for small service providers. Should electronic word-of-mouth be addressed towards local and non-local connections (e.g., a post on Facebook about a service), one could assume that only the electronic word-of-mouth that reaches local contacts is helpful, because only these addressees can use the services of the provider. The electronic word-of-mouth that reaches non-local contacts will probably be useless, because the non-local addressees cannot use the services of the recommended provider. On the contrary, a larger service provider in the same situation (i.e., where electronic word-of-mouth about the provider is spread to local and non-local contacts alike) will find more of the non-local electronic word-of-mouth addressees inside that provider's realm. These addressees can use these services, so the larger provider benefits from electronic word-of-mouth to both local and certain non-local addressees. From this foundation, the following hypothesis is derived:

Hypothesis 1: The more electronic word-of-mouth connections, the more the penetration of word-of-mouth for small local service providers will lag behind larger service providers.

An example can help illustrate this difference between small and larger providers: If one person posts a picture of a Starbucks coffee on their Facebook account, the vast majority of their friends will be able to try the same coffee in their local Starbucks, even if they live far away. But, when posting a picture of a coffee from a small café with only a single branch, only those Facebook friends who live in the same place will be able to react to the electronic word-of-mouth and also try the coffee.

One way for small service providers to overcome this threat is if many of the newly added electronic connections are local. New local connections remain relevant for the small provider, even if they are electronic: the addressee can purchase the service or at least pass on 


\title{
Electronic Word-of-Mouth Communication for Local Service Providers
}

\author{
Nora Schütze
}

the information by word-of-mouth. Thus, there should be fewer differences between larger and small service providers if the electronic word-of-mouth connections are local.

Hypothesis 2: The more local the electronic word-ofmouth communication, the smaller the difference in the penetration of word-of-mouth should be seen between small local service providers and larger service providers.

\section{Word-of-Mouth Simulation in an Agent- Based Network}

The study employs an agent-based simulation of a word-of-mouth process. A growing number of word-ofmouth studies use such agent-based simulations for modelling word-of-mouth processes (Deffuant et al., 2005; Libai et al., 2010). These simulations are fed with behavioural rules for single agents and network specifications as input parameters. After observing the agents' behaviour for multiple rounds, the aggregated consequences of the agents' actions can be observed and traced back to the respective input parameter (Smith \& Conrey, 2007). By systematically varying the inputs, data for statistical analysis is generated. The type of network employed is a small-world network (Watts \& Strogatz, 1998), where the vast majority of relations is clustered locally, but some relations are random to help information travel quickly (Delre et al., 2007b; Dorogovtsev \& Mendes, 2010; Goldenberg et al., 2001; Watts \& Strogatz, 1998).

The actual word-of-mouth communication that is modeled in such a network starts with external effects that go to some agents (e.g., through advertising or actually using the service) and then spread to others via internal effects (Garber et al., 2004; Murray, 1991). This spreading can either happen like a virus infection (Goldenberg et al., 2001) or along the lines of a threshold model (Delre et al., 2007b; Granovetter, 1978; Granovetter \& Soong, 1986).

We simulated a word-of-mouth process in a smallworld network of 2000 agents where $5 \%$ of the relations were random and the rest were locally clustered (Bampo et al., 2008; Garber et al., 2004). The simulation was created in Netlogo (Stonedahl \& Wilensky, 2008; Wilensky, 1999) and was run approximately 600 times. Each simulation included either a small or a larger service provider that differed in reach. Their respective reach was modelled by breaking the two-dimensional network into windows (Garber et al., 2004) and then al- locating more windows to the larger provider and fewer windows to the small provider. Thus, a small local service provider covered approximately $10 \%$ of the network and a larger provider covered approximately $25 \%$, of the network. The infection would only hit an agent if they live within the pre-defined realm of the local service provider and are not immune; $10 \%$ of all agents are set to be immune, which is comparable to "interest state no" in the study by Deffuant and colleagues (2005).

The network was gradually altered to account for the expected rise in electronic communication. The total amount of connections was raised to either $120 \%$ or $140 \%$, creating the variable "added connections". The local share of connections varied: 95, 100, 105, 110 or 115 percentage points were local. The dependent variable is the impact of the word-of-mouth, which measures the share of infected agents in the realm of the local service provider among all agents in this realm after 50 rounds (i.e., the penetration of the population with word-of-mouth communication).

The infection mechanism employs a threshold model and largely relies on extant literature. Nevertheless, one blind spot is being refined: the difference between word-of-mouth from those who actually used a service (i.e., "use agents") and those who only heard about it (i.e.,"hear agents"). We assume that use agents have more powerful word-of-mouth to share than hear agents, which is somewhat similar to Deffuant and colleagues (2005), who model more-convinced agents as being more influential. The infection starts through external effects that exert their influence in every round. It can then take multiple (hierarchical) routes via different thresholds to infect more agents. The size of the threshold ranges from 3 to 6 , depending on whether the word-of-mouth comes from agents who used the service or only heard about it.

\section{Analysis of Data from an Agent-Based Model}

After approximately 600 simulation runs, data on input and output parameters were drawn and analyzed using ordinary least squares regression, because the dependent variable is metric (Goldenberg et al., 2001; Goldenberg et al., 2010). In order to test the hypotheses, three models were developed (Table 1). The first model contains the main effects of the variables "added connections", "local share of connections", and the dummy "small provider", plus the effects of the controls (i.e., external effects through hearsay and use, and infection probability). The second and the third models show 


\section{Electronic Word-of-Mouth Communication for Local Service Providers}

\section{Nora Schütze}

two interaction effects: one between added connections and small providers, the other one between local share of connections and small providers.

Model 1 shows that smaller service providers in general perform worse in terms of the penetration of word-ofmouth, as indicated by the significant negative coefficient for small service providers (Table 1). The main effect of added connections is not significant in the first model, so simply having more connections does not increase the penetration of word-of-mouth. The local share of the connections nevertheless matters strongly for the penetration of word-of-mouth - the significant, positive coefficient shows the positive relationship.

Table 1. Simulation models explaining the penetration of word-of-mouth communication

\begin{tabular}{|c|c|c|c|}
\hline & Model 1 & Model 2 & Model 3 \\
\hline Added connections & $\begin{array}{l}0.009 \\
(0.022)\end{array}$ & $\begin{array}{l}0.090^{* * *} \\
(0.030)\end{array}$ & $\begin{array}{l}0.009 \\
(0.022)\end{array}$ \\
\hline $\begin{array}{l}\text { Share of local } \\
\text { connections }\end{array}$ & $\begin{array}{l}0.491^{* * *} \\
(0.038)\end{array}$ & $\begin{array}{l}0.491^{\text {*** }} \\
(0.038)\end{array}$ & $\begin{array}{l}0.522^{* * *} \\
(0.053)\end{array}$ \\
\hline Small provider & $\begin{array}{l}-0.052^{* * *} \\
(0.005)\end{array}$ & $\begin{array}{l}0.155^{* * *} \\
(0.053)\end{array}$ & $\begin{array}{l}0.013 \\
(0.077)\end{array}$ \\
\hline External use-effect & $\begin{array}{l}0.033^{* * *} \\
(0.001)\end{array}$ & $\begin{array}{l}0.033^{* * *} \\
(0.001)\end{array}$ & $\begin{array}{l}0.033^{* * *} \\
(0.001)\end{array}$ \\
\hline External hear-effect & $\begin{array}{l}0.024^{* * *} \\
(0.002)\end{array}$ & $\begin{array}{l}0.024^{* * *} \\
(0.002)\end{array}$ & $\begin{array}{l}0.024^{* * *} \\
(0.002)\end{array}$ \\
\hline $\begin{array}{l}\text { Probability of } \\
\text { infection }\end{array}$ & $\begin{array}{l}0.001^{* * *} \\
(0.000)\end{array}$ & $\begin{array}{l}0.001^{* * *} \\
(0.000)\end{array}$ & $\begin{array}{l}0.001^{* * *} \\
(0.000)\end{array}$ \\
\hline $\begin{array}{l}\text { Added connections } \\
\mathrm{x} \text { Small provider }\end{array}$ & & $\begin{array}{l}-0.163^{* * *} \\
(0.042)\end{array}$ & \\
\hline $\begin{array}{l}\text { Share of local } \\
\text { connections x Small } \\
\text { provider }\end{array}$ & & & $\begin{array}{l}-0.062 \\
(0.074)\end{array}$ \\
\hline _cons & $\begin{array}{l}-0.555^{* * *} \\
(0.043)\end{array}$ & $\begin{array}{l}-0.658^{* * *} \\
(0.050)\end{array}$ & $\begin{array}{l}-0.587^{* * *} \\
(0.058)\end{array}$ \\
\hline $\mathrm{N}$ & 588 & 588 & 588 \\
\hline adj. R2 & 0.808 & 0.813 & 0.808 \\
\hline
\end{tabular}

Standard errors in parentheses

${ }^{*} \mathrm{p}<0.10,{ }^{* *} \mathrm{p}<0.05,{ }^{* * *} \mathrm{p}<0.01$

www.timreview.ca
The interaction effects necessary to test the hypotheses are provided in Model 2 and 3. The coefficient for the interaction between small providers and added connections (Model 2) is significant and negative, meaning that small providers benefit significantly less from added connections than larger providers do (Table 1). The significant main effect of "added connections" shows that each connection added is positive for larger providers, which means that it increases their penetration of word-of-mouth. For smaller providers, the negative and significant interaction effect shows that their penetration of word-of-mouth will be lower than that of a larger provider once new connections are added, thus supporting Hypothesis 1. Keeping all other factors constant, this negative effect would even mean that the penetration of a small provider is even being harmed by every new connection made. Nevertheless, this is a somewhat theoretical effect: two separate regressions, one for small providers and one for larger providers, were run and the standardized betas (not shown here) were compared, and all the other coefficients do have much higher, significant and positive effects on the penetration of word-of-mouth communication. Thus, it can be concluded that the penetration of the small providers' word-of-mouth communication will be lower than those of the larger providers', but not necessarily negative.

Model 3 shows the interaction between the local share of connections and small provider, allowing for the test of Hypothesis 2. The coefficient for the interaction does not become significant (Table 1), thus there is no significant difference between large and small providers in terms of how they benefit from a higher share of local connections. This result shows that Hypothesis 2 also finds support in the data.

In summary, larger providers benefit much more than small providers from a growth in the number of connections their customers have. Only if these new connections are mainly local, do small providers and larger providers experience similar penetration of word-ofmouth.

To further illustrate these differences, the data were sorted into eight groups. The groups were formed by crossing the variables "added connections", "share of local connections", and "small provider". Four of the groups represent small providers (denoted with solid lines in Figure 1); the other four represent larger providers (denoted with dotted lines in Figure 1). 


\section{Electronic Word-of-Mouth Communication for Local Service Providers}

\section{Nora Schütze}

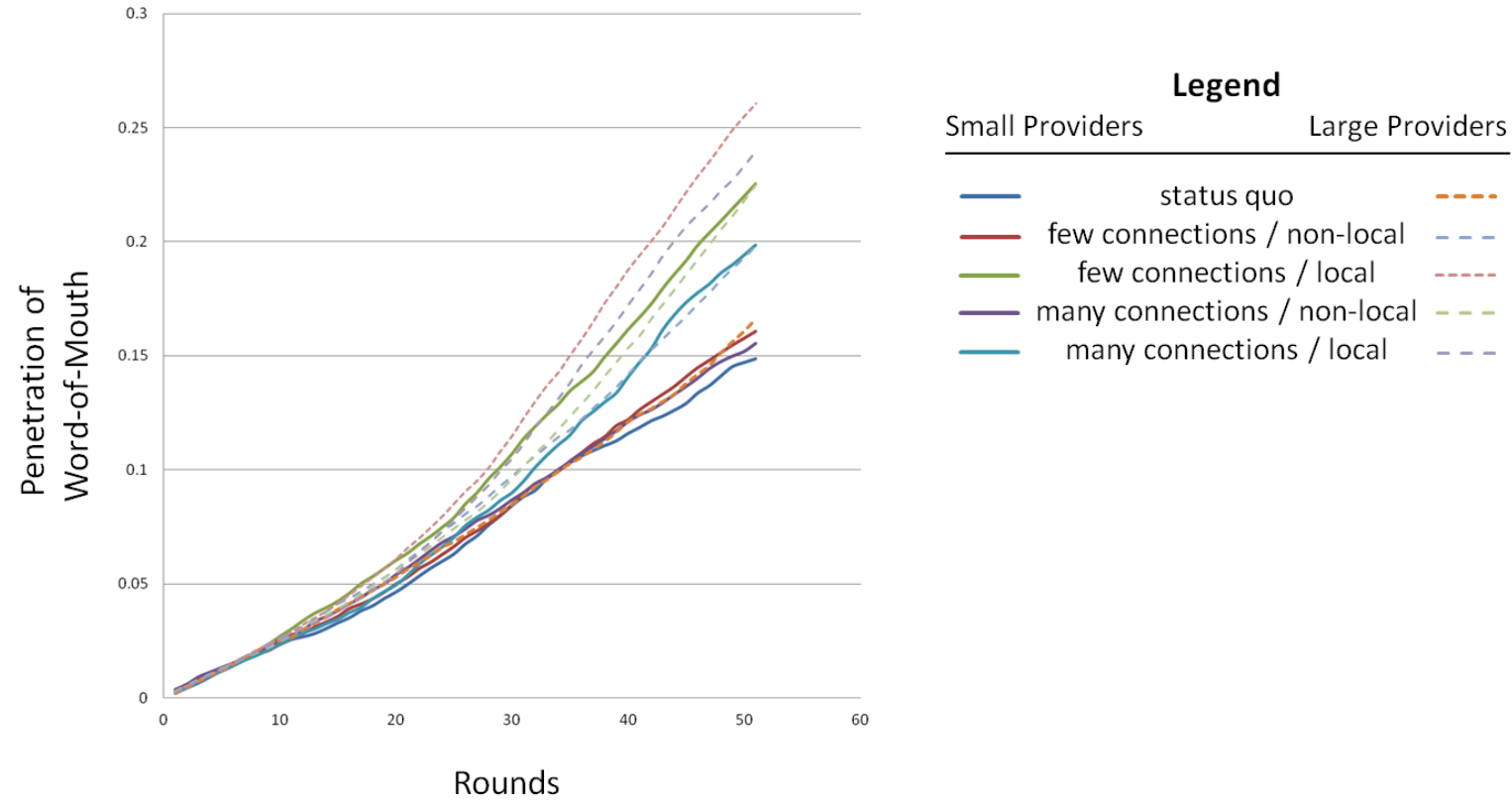

Figure 1. Simulated penetration of word-of-mouth communication by service-provider group

The simulation shows that, for small as well as for larger providers, adding connections and increasing the local share results in higher penetration of word-of-mouth. Nevertheless, for the small providers, the improvement versus the status quo is rather small if most connections are non-local, no matter how many new connections are added. Only if many of the connections are local, can a small provider truly benefit. For larger providers, the picture is different: they are positively affected by both factors, added connections and higher local share of connections.

Another interesting aspect of Figure 1 is the development of the penetration over time. The "take-off" of the better-performing groups only starts after about 30 rounds. This finding points to the self-reinforcing effect of word-of-mouth (Winch \& Bianchi, 2006) that only exerts its influence once the external effects have reached a certain size.

The point of the simulation could be empirically validated by studying actual word-of-mouth and electronic word-of-mouth processes of small and larger service providers. All of their word-of-mouth communications should be gathered over a certain time period and then be compared in terms of penetration and the impact of the proximity of the electronic contacts. Alternatively, only gathering the electronic word-of-mouth could suffice to make the point of differences in penetration between small and larger providers, and the impact of distant electronic word-of-mouth recipients.

\section{Recommendations for Small Service Providers}

Small local service providers could take the following actions to benefit from increased electronic word-ofmouth communication:

1. Foster word-of-mouth communications, especially those that are local and electronic: Most local service providers treat word-of-mouth as something out of their influence that just "comes naturally". With the danger of losing penetration of word-of-mouth due to increased electronic communication, local service providers should make an effort to foster word-ofmouth, for example, by implementing a "Tell a friend" program. The more word-of-mouth communication there is (be it face-to-face or electronic), the more self-reinforcing it becomes. An important facet of such a program is stimulating local electronic word-of-mouth, that is encouraging local customers to talk to their local online connections about a provider, for example, by offering local prizes for every 100th post about the provider or service in a social network. Local electronic word-of-mouth will be of utmost importance to local service providers because it helps to reinforce the normal word-ofmouth and thus to maintain its penetration. It also reacts to the customers' need for online communication. 


\title{
Electronic Word-of-Mouth Communication for Local Service Providers
}

\author{
Nora Schütze
}

\section{Aggregate electronic word-of-mouth and channel it to} its own servicing area: This article shows that the penetration of word-of-mouth decreases when electronic word-of-mouth leaves the service provider's realm and cannot "find a way back" to the local context by itself. Still, there are ways for a provider to help channel this electronic word-of-mouth back into its local area. For example, the service provider could implement a mechanism for collecting electronic word-ofmouth communication about it services and then create links from these communications back to the offline world, for example by printing electronic posts on cards to hang up on the shop walls, and to its own web presence, for example by retweeting word-of-mouth messages posted on Twitter by the provider's customers.

3. Find new ways to combine word-of-mouth and electronic word-of-mouth: For the self-reinforcing effect of word-of-mouth to unfold, it is necessary for the communications to easily change channels, for example, to go from face-to-face to electronic and back. Finding technical ways to ensure a smooth and easy transition from one means of communication to another will promote the penetration of word-ofmouth. This need for an easy transition not only holds true for the rather coarse distinction between word-of-mouth and electronic word-of-mouth, but also for transitions between subcategories such as email, tweets, Facebook likes, feedback on websites, received oral feedback, and so on.

4. Extend reach by cooperating with competitors: Reach is key for a local service provider, as shown in this study. One innovative way to fight off decreased penetration of word-of-mouth would be to cooperate with other local service providers in order to increase reach. These other providers should at best be providers in the same line of business, but in another geographical area. Reach could increase fundamentally if some providers from different areas marketed their services together online. Electronic word-ofmouth for such an alliance could hardly leave the combined realm, so the penetration of word-ofmouth would stay high. Furthermore, resource pooling could help advance the above-mentioned innovations.

\section{Conclusion}

This article shows that small local service providers may suffer from the increased digitization of communication. Relative to large service providers, the import- ant marketing tool of word-of-mouth might leave small service providers worse off in terms of penetration. The agent-based simulation used in this study shows that this gap grows wider as the number of electronic connections increases. Electronic connections often link people who are distant, that is, who do not live within the realm of a small service provider. Word-of-mouth distributed to those people could be less helpful to a small and locally restricted service provider, because the recipients living outside of his realm cannot purchase the service and will probably not spread the word about it.

The simulation also shows that this challenge may be largely overcome if the online connections are as local as possible, meaning that local service providers can benefit from increased levels of electronic word-of-mouth if those electronic communications are targeted at people living nearby. If this is the case, the difference in the penetration of word-of-mouth for small and larger providers is expected to be smaller.

However, there are several limitations pertaining to the analysis. First, the goal of this study was to investigate the role of physical proximity in influencing the effects of electronic word-of-mouth for small local service providers. Thus, physical proximity lies at the core of the analysis and other factors that might impact the effects of electronic word-of-mouth, such as the strength of ties between connections, are ignored. The effects of tie strength have been debated in the literature: although strong ties are more influential than weak ties in the awareness phase of a purchase (De Bruyn \& Lilien, 2008), weak ties have been shown to be more influential than strong ties once the size of a person's network decreases or when there are many contacts with weak ties (Goldenberg et al., 2001). Depending on the proximity of strong and weak ties, the impact of tie strength might influence the effects of physical proximity. An examination of this factor (and others) could be an interesting extension to the research discussed here. Second, a more fine-grained simulation could include more aspects of the word-of-mouth process (e.g., the valence of the word-of-mouth) or further detail out the behaviour of the agents. Third, the predictive power of the simulation could be increased with real-world data instead of basing the simulation on parameters drawn from the literature.

Despite these limitations, the study suggests that small service providers can improve the penetration of their word-of-mouth to benefit from electronic communication. Such innovative solutions could aim at supporting 


\section{Electronic Word-of-Mouth Communication for Local Service Providers}

\section{Nora Schütze}

local electronic connections to invoke local electronic word-of-mouth, but need not be confined to this approach. Four recommendations for small service providers were offered here: i) fostering word-of-mouth and electronic word-of-mouth; aggregating and channeling electronic word-of-mouth into the provider's own servicing realm; searching for new ways of combining face-to-face word-of-mouth and electronic word-ofmouth; and extending the reach of small service providers, for example, through alliances with providers from different areas but from the same line of business.

\section{References}

Agrawal, A., Kapur, D., \& McHale, J. 2008. How Do Spatial and Social Proximity Influence Knowledge Flows? Evidence from Patent Data. Journal of Urban Economics, 64(2): 258-269.

http://dx.doi.org/10.1016/j.jue.2008.01.003

Arndt, J. 1967. Role of Product-Related Conversations in the Diffusion of a New Product. Journal of Marketing Research, 4(3): 291-295. http://dx.doi.org/10.2307/3149462

Bampo, M., Ewing, M. T., Mather, D. R., Stewart, D., \& Wallace, M. 2008. The Effects of the Social Structure of Digital Networks on Viral Marketing Performance. Information Systems Research, 19(3): 273-290.

http://dx.doi.org/10.1287/isre.1070.0152

Bell, D. R. \& Song, S. 2007. Neighborhood Effects and Trial on the Internet: Evidence from Online Grocery Retailing. Quantitative Marketing and Economics, 5(4): 361-400.

http://dx.doi.org/10.1007/s11129-007-9025-5

Bronnenberg, B. J. \& Mela, C. F. 2004. Market Roll-Out and Retailer Adoption for New Brands. Marketing Science, 23(4): 500-518. http://dx.doi.org/10.1287/mksc.1040.0072

Carl, W. J. 2006. What's All The Buzz about? Everyday Communication and the Relational Basis of Word-of-Mouth and Buzz Marketing Practices. Management Communication Quarterly, 19(4): 601-634. http://dx.doi.org/10.1177/0893318905284763

Choi, J., Hui, S. K., \& Bell, D. R. 2010. Spatiotemporal Analysis of Imitation Behavior Across New Buyers at an Online Grocery Retailer. Journal of Marketing Research, 47(1): 75-89.

http://dx.doi.org/10.1509/jmkr.47.1.75

De Bruyn, A. \& Lilien, G. L. 2008. A Multi-Stage Model of Word-ofMouth Influence through Viral Marketing. International Journal of Research in Marketing, 25(3): 151-163. http://dx.doi.org/10.1016/j.ijresmar.2008.03.004

Deffuant, G., Huet, S., \& Amblard, F. 2005. An Individual-Based Model of Innovation Diffusion Mixing Social Value and Individual Benefit. American Journal of Sociology, 110(4): 1041-1069. http://dx.doi.org/10.1086/430220

Delre, S. A., Jager, W., Bijmolt, T. H. A., \& Janssen, M. A. 2007. Targeting and Timing Promotional Activities: An Agent-Based Model for the Takeoff of New Products. Journal of Business Research, 60(8): 826-835.

http://dx.doi.org/10.1016/j.jbusres.2007.02.002

\section{About the Author}

Nora Schütze is a PhD student at Cottbus University of Technology, Germany. Her current research focuses on e-commerce and the network formation phase of small service providers. In addition to her research, she works as a management consultant to help clients change mindsets and behaviours. She has also studied sociology and political science at the University of Mannheim, Germany.

Delre, S. A., Jager, W., \& Janssen, M. A. 2007. Diffusion dynamics in small-world networks with heterogeneous consumers. Computational and Mathematical Organization Theory, 13(2): 185-202.

http://dx.doi.org/10.1007/s10588-006-9007-2

Dennis, A. R., Fuller, R. M., \& Valacich, J. S. 2008. Media, Tasks, and Communication Processes: A Theory of Media Synchronicity. MIS Quarterly, 32(3): 575-600.

Dorogovtsev, S. N. \& Mendes, J. F. F. 2003. Evolution of Networks: From Biological Nets to the Internet and WWW. Oxford: Oxford University Press.

East, R., Hammond, K., Lomax, W., \& Robinson, H. 2005. What is the Effect of a Recommendation? The Marketing Review, 5(2): 145-157. http://dx.doi.org/10.1362/1469347054426186

Garber, T., Goldenberg, J., Libai, B., \& Muller, E. 2004. From Density to Destiny: Using Spatial Dimension of Sales Data for Early Prediction of New Product Success. Marketing Science, 23(3): 419-428.

http://dx.doi.org/10.1287/mksc.1040.0051

Godes, D., Mayzlin, D., Chen, Y., Das, S., Dellarocas, C., Pfeiffer, B., et al. 2005. The Firm's Management of Social Interactions. Marketing Letters, 16(3-4): 415-428.

http://dx.doi.org/10.1007/s11002-005-5902-4

Goldenberg, J., Libai, B., \& Muller, E. 2001. Talk of the Network: A Complex Systems Look at the Underlying Process of Word-ofMouth. Marketing Letters, 12(3): 211-223.

http://dx.doi.org/10.1023/A:1011122126881

Goldenberg, J., Libai, B., \& Muller, E. 2010. The Chilling Effects of Network Externalities. International Journal of Research in Marketing, 27(1): 4-15.

http://dx.doi.org/10.1016/j.ijresmar.2009.06.006

Granovetter, M. 1978. Threshold Models of Collective Behavior. American Journal of Sociology, 83(6): 1420-1443. http://www.jstor.org/stable/2778111

Granovetter, M. \& Soong, R. 1986. Threshold models of interpersonal effects in consumer demand. Journal of Economic Behavior \& Organization, 7(1): 83-99.

http://dx.doi.org/10.1016/0167-2681(86)90023-5 


\section{Electronic Word-of-Mouth Communication for Local Service Providers}

\section{Nora Schütze}

Keller, E. \& Berry, J. 2006. Word-of-mouth: The real action is offline. The Keller Fay Group. April 1, 2014:

http://www.kellerfay.com/word-of-mouth-the-real-action-isoffline/

Keller, E. \& Fay, B. 2012. The Face-to-Face Book: Why Real Relationships Rule in a Digital Marketplace (First Edition edition.). New York: Free Press.

Lagrosen, S. 2005. Effects of the Internet on the Marketing Communication of Service Companies. Journal of Services Marketing, 19(2): 63-69. http://dx.doi.org/10.1108/08876040510591376

Libai, B., Bolton, R., Bügel, M. S., Ruyter, K. de, Götz, O., Risselada, H., et al. 2010. Customer-to-Customer Interactions: Broadening the Scope of Word of Mouth Research. Journal of Service Research, 13(3): 267-282.

http://dx.doi.org/10.1177/1094670510375600

Libai, B., Muller, E., \& Peres, R. 2009. The Diffusion of Services. Journal of Marketing Research, 46(2): 163-175. http://dx.doi.org/10.1509/jmkr.46.2.163

Lovelock, C. H. \& Wirtz, J. 2010. Services Marketing (7th edition.). Boston: Prentice Hall.

Murray, K. B. 1991. A Test of Services Marketing Theory: Consumer Information Acquisition Activities. Journal of Marketing, 55(1): 10. http://dx.doi.org/10.2307/1252200

Smith, E. R. \& Conrey, F. R. 2007. Agent-Based Modeling: A New Approach for Theory Building in Social Psychology. Personality and Social Psychology Review, 11(1): 87-104. http://dx.doi.org/10.1177/1088868306294789

Stonedahl, F. \& Wilensky, U. 2008. NetLogo Virus on a Network model. Center for Connected Learning and Computer-Based Modeling, Northwestern University, Evanston, IL. http://ccl.northwestern.edu/netlogo/models/VirusonaNetwork
Subramaniam, C., Shaw, M. J., \& Gardner, D. M. 2000. Product Marketing and Channel Management in Electronic Commerce. Information Systems Frontiers, 1(4): 363-378. http://dx.doi.org/10.1023/A:1010061924822

Trusov, M., Bucklin, R. E., \& Pauwels, K. H. 2008. Effects of Word-ofMouth Versus Traditional Marketing: Findings from an Internet Social Networking Site. Robert H. Smith School Research Paper No. RHS 06-06: 49. http://papers.ssrn.com/abstract=1129351

Van den Bulte, C. \& Wuyts, S. 2007. Social Networks and Marketing. Cambridge, MA: Marketing Science Institute.

Watts, D. J. \& Strogatz, S. H. 1998. Collective Dynamics of "SmallWorld" Networks. Nature, 393(6684): 440-442. http://dx.doi.org/10.1038/30918

Wellman, B. 1996. Are Personal Communities Local? A Dumptarian Reconsideration. Social Networks, 18(4): 347-354. http://dx.doi.org/10.1016/0378-8733(95)00282-0

Wilensky, U. 1999. NetLogo. Center for Connected Learning and Computer-Based Modeling, Northwestern University, Evanston, IL. http://ccl.northwestern.edu/netlogo/

Winch, G. W. \& Bianchi, C. 2006. Drivers and Dynamic Processes for SMEs Going Global. Journal of Small Business and Enterprise Development, 13(1): 73-88. http://dx.doi.org/10.1108/14626000610645324

Wuyts, S. \& van den Bulte, C. 2007. Social Networks and Marketing. Cambridge, MA: Marketing Science Institute.

Zeithaml, V. A. 1981. How Consumer Evaluate Processes Differ between Goods and Services. Marketing of Services: 1. Chicago: American Marketing Association.

Zeithaml, V., Bitner, M. J., \& Gremler, D. 2012. Services Marketing: Sixth Edition. McGraw-Hill Higher Education. 